\title{
Sources and Acknowledgments
}

This book originated in newspaper and magazine articles I'd been writing over more than fifteen years on the increasingly intense controversies about immigration and American immigration policy and the many issues related to them. In the course of that work I was often surprised that the great volume of material on the history of American immigration and its discontents, which is often so relevant to our contemporary debates, had been so consistently ignored in those debates-sometimes, it seemed, almost deliberately so. There is a vast amount of it, some going back to the earliest years of the Republic and in some cases to the colonial period-orders of colonial governors; the writings of Benjamin Franklin and Thomas Jefferson and the Declaration of Independence itself; records of congressional hearings and debates; papers and reports of the many groups that have sought to shape immigration policy; "scientific" studies and analyses on the various "races" coming to this country or hoping to come; magazine and newspaper articles; speeches of political leaders; broadsides issued by lobbies and political parties. In addition, there is a rich trove of secondary sources that sheds light not only on our history but on the ideas and organizations at the forefront of today's immigration fight.

I've drawn freely from it, most of it cited in the notes at the end of the book. What could not be fully credited or attributed without cluttering 
the story with an excess of footnotes and textual distractions are many of the hundreds of journals, magazine articles, cartoons, broadsides, photographs, and other documents I found so useful in the American Time Capsule and other collections of the Library of Congress; the voluminous material in the report of the U.S. Immigration Commission (the Dillingham Commission) and that of the National Commission on Law Observance and Enforcement (the Wickersham Commission); the reports of the House Committee on Immigration and Naturalization and other congressional documents; the historical statistics of the Census Bureau; the immigration documents of the Labor, Commerce, Justice and State departments and the Department of Homeland Security; the papers on eugenics and immigration policy in the Harry $\mathrm{H}$. Laughlin collection of the Pickler Memorial Library at Truman State University in Kirksville, Missouri, and in the Open Collections Program on immigration at the Harvard University Library; the image archive of the Eugenics Movement; the archives of the Eugenics Record Office at the American Philosophical Society in Philadelphia; the Electronic Text Center of the University of Virginia Library; the Avalon Project at the Yale Law School; the California State Archives in Sacramento and the Oregon State Archives in Salem; the electronic archives of the New York Times dating back to the 1850 as well as the archives of CNN, the Los Angeles Times, and other publications and broadcasters of more recent vintage.

I also relied on more secondary sources-books and journal articlesthan I can possibly credit or, in some cases, even recall. Among the most important: Ray Allen Billington's Protestant Crusade I800-I860: A Study of the Origins of American Nativism; John Higham's Strangers in a Strange Land: Patterns of American Nativism I860-1925; Henry Nash Smith's Virgin Land: The American West as Symbol and Myth; Vernon L. Parrington's Main Currents in American Thought; Oscar Handlin's Uprooted; Richard Alba and Victor Nee's Remaking of the American Mainstream: Assimilation and Contemporary Immigration; Richard Hofstadter's Age of Reform: From Bryan to F.D.R.; Matthew Frye Jacobson's Whiteness of a Different Color: European Immigrants and the Alchemy of Race; Richard Roediger's Working toward Whiteness: How American's Immigrants Became White; Dowell Myers's Immigrants and Boomers: Forging a New Social Contract for the Future of America; Mae M. Ngai's Impossible Subjects: Illegal Aliens and the Making of Modern America; Daniel J. Kevles's In the Name of Eugenics: Genetics and the Uses of Human Heredity; and Edwin Black's War against the Weak: Eugenics and America's Campaign to Create a Master Race. 
I'm also grateful to many individuals and organizations-among them Steven Camorata of the Center for Immigration Studies; Douglas Rivlin of the National Immigration Forum; Angela Kelley of the Immigration Policy Center; Michael Fix of the Migration Policy Institute; Jeffrey Passel of the Pew Hispanic Center; Hans Johnson of the Public Policy Institute of California; Professor Belinda Reyes of San Francisco State University; Professor Dowell Myers of the University of Southern California; California state senator Gil Cedillo; James P. Smith of the Rand Corporation; Professor Jack Citrin, director of the Institute for Governmental Studies at the University of California at Berkeley; and Marian L. Smith of the Department of Homeland Security-for their help in research for this book and/or in my reporting on immigration issues over a period of many years. In the course of my research, I also realized again how much I owed to my own teachers of American history and literature, among them Professors Henry Steele Commager and Leo Marx, and to my late friend and Amherst colleague John William Ward.

Last, but far from least, I'm especially indebted to Professor David Hollinger of the University of California at Berkeley; my longtime friends and former Sacramento Bee colleagues Claire Cooper and Mark Paul, the latter now of the New America Foundation, for their sympathetic and very helpful reading of an early draft of this book; to Naomi Schneider, my editor at the University of California Press; and, as ever, to Patricia Ternahan for all of the above and a great deal more. 
This page intentionally left blank 